\title{
The relative performance of foreign-owned subsidiaries and domestic companies
}

DOI:

$10.1080 / 14631377.2018 .1505692$

\section{Document Version}

Accepted author manuscript

Link to publication record in Manchester Research Explorer

\section{Citation for published version (APA):}

Marinescu, N., Constantin, C. E., \& Haar, L. (2018). The relative performance of foreign-owned subsidiaries and domestic companies. Post-Communist Economies. https://doi.org/10.1080/14631377.2018.1505692

\section{Published in:}

Post-Communist Economies

\section{Citing this paper}

Please note that where the full-text provided on Manchester Research Explorer is the Author Accepted Manuscript or Proof version this may differ from the final Published version. If citing, it is advised that you check and use the publisher's definitive version.

\section{General rights}

Copyright and moral rights for the publications made accessible in the Research Explorer are retained by the authors and/or other copyright owners and it is a condition of accessing publications that users recognise and abide by the legal requirements associated with these rights.

\section{Takedown policy}

If you believe that this document breaches copyright please refer to the University of Manchester's Takedown Procedures [http://man.ac.uk/04Y6Bo] or contact uml.scholarlycommunications@manchester.ac.uk providing relevant details, so we can investigate your claim.

\section{OPEN ACCESS}




\title{
The relative performance of foreign-owned subsidiaries and domestic companies
}

\author{
Nicolae Marinescu ${ }^{1}$, Cristinel Constantin ${ }^{2}$, Laura N. Haar ${ }^{3}$ \\ ${ }^{1,2}$ Transilvania University of Brasov, Romania, ${ }^{3}$ University of Manchester, UK
}

Nicolae Marinescu, PhD, Assoc. Prof. at the MTSAI Department, Faculty of Economics \& Business Administration, Transylvania University of Brasov, Bd. Eroilor 29, 500036 Brasov, Romania, Tel.: +40.722.533912. Email: marinescu@unitbv.ro

Cristinel Constantin, PhD, Prof. at the MTSAI Department, Faculty of Economics \& Business Administration, Transylvania University of Brasov, Bd. Eroilor 29, 500036 Brasov, Romania, Tel.: +40.727.392380. Email: cristinel.constantin@unitbv.ro

Laura N. Haar, PhD, Assistant Prof. at Alliance Manchester Business School, The University of Manchester, Booth Street West, Manchester, M15 6PB, United Kingdom, Tel.: +44(0)161.3068790. Email: laura.n.haar@manchester.ac.uk

\begin{abstract}
The paper investigates the financial performance of the largest firms in Romania, by comparing foreign-owned subsidiaries (FOS) and domestic companies (DCs) over a decade. As such, the paper contributes to the literature on foreign direct investment (FDI) in transition economies, focusing on a country where few such studies have been conducted previously. Whereas most microeconomic research published about Central and Eastern European (CEE) economies is concerned with the effects of FDI, albeit positive or negative, this paper fills a gap in the literature by comparing the evolution of FOS and DCs performance during 2003-2012. This matter is approached in a novel methodological way, by applying the multiple correspondence analysis to explain the complex relationships between ownership, modes of entry and
\end{abstract}


performance, as reflected in turnover and profit margins. One result is that FOS replaced DCs in top national positions, when taking into account size and turnover. However, although FDI via acquisitions financially outperformed DCs, the latter did better than greenfield FDI after the global economic crisis. Of all the factors analysed, the sector of activity resulted as having by far the most important influence on financial performance. The results have implications for policymakers who design FDI programmes for economic development.

Keywords: Acquisitions, Greenfield FDI, Foreign-Owned Subsidiaries, Domestic Companies

\section{Introduction}

At the beginning of 1990s Romania started the process of economic restructuring to transition from a central planning system to a market economy. The country introduced an open-door policy to FDI, irrespective of modes of entry, foreign nationality and sector. Those FDI-related policies were validated in academic research showing how host countries benefitted from FDI in the form of accelerated growth on the back of improved export performance, technology, infrastructure and human development through spill over effects or positive externalities, knowledge transfer and increased competition (Ghauri \& Yamin, 2009; Navaretti \& Venables, 2013). Further it has been shown that spill-over effects may take the form of subsidiaries using financial resources to develop business networks with local small and medium enterprises (SMEs) which contribute to economic development of the host countries (Nguyen, 2013). In some countries of Central and Eastern Europe (CEE) such as Hungary and the Czech Republic, FDI has been associated with faster growth rates leading at times to spill over effects from multinational companies (MNEs) to domestic incumbents. Some studies claim that spill over effects are more evident in capital and R\&D intensive industries and, as such, FDI in these 
sectors should be promoted to accelerate technical progress (Javorcik \& Spatareanu, 2011; Sanchez-Sellero et al., 2014). In the CEE region, Damijan et al. (2013) studied ten economies in transition and found that the extent of positive externalities depended on the absorptive capacity and the productivity level of industrial firms. More generally, Mehic et al. (2013) argued that FDI also contributed to economic growth in Southeast Europe through encouraging domestic investment.

However, positive spill over effects of FDI in CEE remain a contested territory. In the early stages of transformation after the 1990s, the purported benefits of FDI were illusive. MNEs typically formed few linkages with local firms, which offered low-skilled jobs involving manufacturing based on mass production technology (Hardy et al., 2011).

At the same time, contrasting views have emerged that FDI may have adverse effects upon host economies (Jensen, 2006; Narula \& Driffield, 2011). At macro-level, investment should translate into higher growth rates and development, but at micro-level, there may be adverse effects for DCs. There is evidence that sometimes DCs are forced to exit the market when FOS enjoyed preferential access, including more favourable tax regimes compared to their domestic rivals. Although there is ample research on entry modes to emerging markets, the performance of FOS as well as their impact on DCs has received less attention (Narula \& Dunning, 2010; Nguyen, 2011). There has been some research on subsidiary performance in China and other Asian nations along with the impact of FDI on domestic firms but in CEE this subject has received less attention (Nguyen \& Rugman, 2015).

To address this gap in the literature, in this paper we compare the relative performance of FOS firms in their FDI programs versus the performance of domestic firms using a large CEE economy using data of the last decade. Comparing empirical analysis of the characteristics and 
performance of foreign-owned subsidiaries (FOS) versus those of domestically-owned counterparts (DCs), the research sheds light on the differences and their explanatory factors. Through analysis of the comparative performance of FOS versus DCs we gain insight into the impact of such inward investment upon incumbent domestic firms. The paper extends previous research on the characteristics of FDI in CEE that highlighted (1) the prevalence of acquisitions and greenfield FDI as the dominant entry modes and (2) the tendency for acquisitions to display higher profit margins and turnover when compared to greenfield FDI (see, for example, Haar \& Marinescu, 2014). In addition, through our empirical data we can compare the relative performance of FOS and DCs. As data we use the largest 100 companies by turnover in Romania since 2003, the first year when comprehensive and reliable data on FOS has been collected by the Centre for Economic Modelling (CERME), a research institute publishing data annually by Finmedia. With the help of cross-sectional, longitudinal data, we investigate and explain how variations in turnover or revenues relate to performance (profit margin) of DCs and FOS across modes of entry and sectors. We categorize explanatory factors to explore how they interact using multiple correspondence analysis (also known as homogeneity analysis, or HOMALS). Our work expands upon previous research by applying this form of analysis to examine the differences between FOS and DCs in a transition economy (Barbosa \& Louri, 2005; Bellak, 2004; Damijan et al., 2013; Jenkins, 1990; Mata \& Portugal, 2004; Mehic et al., 2013; Rugman \& Verbeke, 2001).

The paper is structured as follows: section 2 presents a literature review of the differences in performance between foreign subsidiaries and domestic companies, both in general and in countries of CEE in particular; section 3 introduces data and research methodology and, in section 4, we review our analysis. The paper concludes with highlighting the contribution of this 
study to the comparative performance of FOS and DCs in a transition economy and the policy aspects that can be derived from the findings.

\section{Relative performance of foreign-owned subsidiaries and domestic firms in theory and practice}

International business research on the relative performance of FOS and their domestic rivals continues early explanations of multinational enterprises (MNEs). The main theoretical explanations of MNEs concern such areas as the boundaries of the firm, transaction costs theory, internalisation theory and culminate in the well-known ownership-location-internalisation (OLI) paradigm of Dunning (Buckley \& Casson, 1976; Dunning, 1973; Hymer, 1976). Such contributions postulate that MNEs enjoy superior performance in the main because of their firmspecific advantages, carefully developed in their home markets and deployed overseas through

their subsidiaries (Dunning, 1973; Markusen, 1995). Such firm-specific advantages are difficult to replicate by firms focused solely upon a domestic market. Further, according to this narrative, such firm-specific advantages of MNEs should exceed any location-based advantages enjoyed by DCs in order to overcome MNEs' 'liability of foreignness', i.e. the costs associated with doing business abroad. Examples of firm-specific advantages may be financial (easier access to capital markets, low-interest intra-firm lending), technological (as result of higher R\&D investment, first movers advantages in capital-intensive industries), marketing, managerial know-how and other intangible advantages (Aitken \& Harrison, 1999).

In addition to the above advantages enjoyed by MNEs over DCs, new research has highlighted the organisational advantages of FOS. For example, Rugman \& Verbeke (2001) identified multiple types of MNE-subsidiary linkages leading to subsidiary-specific advantages 
that derive from the fact that subsidiaries are part of the wider organisational structure of an MNE. In all, it has been argued that such firm-specific advantages allow subsidiaries to enter foreign markets and outperform locally-owned firms despite the costs faced when operating in an unfamiliar environment (Hamida, 2013; Nguyen \& Rugman, 2015). Notwithstanding such findings of positive relationship between foreign ownership and performance, categorical empirical evidence on the superior performance of FOS versus those of DCs is not sufficiently approached in the literature, especially not in the CEE region. The present study attempts to dwell into a more detailed analysis, trying to fill a gap in the literature concerning the comparative financial performance of FOS and DCs. The methodological approach is a novel one, employing a multiple correspondence statistical analysis (see section 3).

Reviewing the above research we see there are varied approaches to comparing the performance of FOS with their domestic competitors. Some authors use well-known financial metrics such return on capital employed, return on assets, return on equity but others look at employment, sales, market share etc. According to some cross-sectional studies there is evidence that foreign subsidiaries of MNEs out-performed their domestic counterparts, especially so in developing countries (Caves, 1996; Findlay, 1978). Some studies of FDI suggest a positive relationship between nationality and general performance (Ashraf \& Herzer, 2014; Narula \& Dunning, 2010); others have found in empirical investigations that FOS do not consistently outperform domestic rivals in general, unless judged by profitability alone (Barbosa \& Louri, 2005; Majumdar, 1997). Altogether a synthesis of empirical findings with theory has yet to emerge.

From a host-country perspective, foreign acquisitions of domestic entities can be a source of capital and firm-specific competencies but may create local antipathy as they gain 
market share from domestic rivals. For example, acquired domestic firms might be forced to exclude local suppliers, to limit production to low value-added activities, import higher-value intermediate products and lay off workers. Thus a decline in employment may follow when the acquired companies are undergoing restructuring. Several studies found that employment in privatised firms usually falls, although in one study, jobs were saved when MNEs acquired ailing domestic firms (Szentpeteri \& Telegdy, 2012; UNCTAD, 2004). Furthermore, acquisition oriented FDI could have adverse effects when MNEs close down acquired firms. Unlike acquisitions, greenfield FDI appears to have a better record in countries of the CEE, especially with regard to market structure, as they increase competition, force local firms to improve efficiency or exit the market. Some research has underscored the importance of technology transfer and product upgrading, important to transition economies. In this regard, there is evidence that FDI has been instrumental in changing the industrial specialisation of most advanced CEECs and contributing to their export competitiveness, especially towards the EU single market (Bandelj, 2010; Hunya, 2001). Or for example, Marinescu \& Constantin (2010) argued that the largest FDI inflows in Romania targeted newly privatised industrial companies that already enjoyed above average export propensity. Modes of entry to new markets may also be different for MNE versus incumbent domestic firms. Their respective approaches to how they control costs or manage subsidiaries may be distinct (Nitsch et al., 1996; Wang \& Wang, 2015). Some researchers have examined the effects of FDI upon the productivity of DCs as positive irrespective of entry mode, on the grounds of an increased competition from FOS that benefit from transfer of technology, capital and skills from the parent company (Javorcik, 2004). Through gaining ascendancy, it was shown that greenfield FDI was more likely to drive local firms out of the market. While in final product markets, FDI led to foreign affiliates gaining 
ascendancy in certain markets because they were more efficient than domestic firms, irrespective of their entry mode (UNCTAD, 2000). Some researchers have examined how entry modes influence performance by examining the post-entry growth and survival of FOS and argued that the choice of entry mode has a long-term effect on performance (Mata \& Portugal, 2004). Also, some sectors such as the less capital intensive may enjoy greater profit margins than others and, therefore, the relative performance of FOS and DCs may be influenced by the nature of their industry (Sanchez-Sellero et al., 2014). But few studies have analysed entry modes and performance of FOS in comparison with domestic rivals.

To extend the above research, we compare the financial performance of subsidiaries of MNEs, both greenfield ventures and acquisitions with that of domestic firms introducing into our analysis modes of market entry. We use for research data from one of the largest CEE countries, Romania, since 2003, from when financial indicators began to be collected systematically on the country's largest firms. Our main objective is to seek whether there is evidence to support the assertion that the arrival of large FOS affected the number and performance of DCs in our defined population of firms. In order to reach this objective, the following research questions have been established: (1) Is there evidence of foreign firm gaining ascendancy over domestic firms, post-entry or do foreign and domestic firms continue to perform equally? (2) Are there differences in profitability among DCs, acquisition FOS and greenfield FOS? (3) How did corporate performance vary across sectors (industry, trade and services)?

Ten years after the major privatisation programmes, we seek to explore how foreign investors performed compared to domestic rivals. In what follows we introduce our data set and research method employed to analyse and compare the performance of similar size foreignowned versus domestic companies in Romania from 2003 to 2012. 


\section{Data and research methodology}

Comparing the performance of domestic firms with the subsidiaries of multinational companies has several challenges. Without knowledge of cost structure and cost allocation, how resources are used, how committed are management resources, may together make head-line results like turnover difficult to interpret or meaningless. Ultimately, which indicators are chosen is often a matter largely determined by data availability and the exact scope of research. Our population consists of the largest firms by turnover, with data on profit margins, defined as the ratio of gross profit to revenue or turnover. We have chosen large firms due to their ability to obtain high performance: they can take advantage of economies of scale and scope and may organise their activities more efficiently. To observe changes in the composition and performance of inward FDI over time we used annual data for the largest 100 companies in Romania by turnover for the period 2003-2012, a decade that had witnessed not only major changes in corporate ownership but also financial turmoil. Our unit of analysis is the firm and we distinguish between DCs, acquisition and greenfield FOS. The database is compiled annually by the Romanian Centre of Economic Modelling (CERME), a think-tank and is released through Finmedia. We used this firm level data base due to the difficulty to obtain financial data about individual companies over such a long period. In this respect the Top 100 is regarded as the most reliable source of company information, which uses a consistent methodology over the years. The database has a limited sample of the total FOS in Romania, with around seventy FOS each year but this sample can help us observe the evolution of the performance obtained by the most important companies in Romania. The database contains individual recordings about the firms' turnover, profit margin, and sector, included in pre-defined categories as shown in table 1. 
[Table 1 here]

In order to highlight the relationship between the sector and the other variables, the analysed companies have been divided into three categories: industry (manufacturing and mining); trade (wholesale and retail); and services (transport, telecommunications, tourism, construction, utilities).

The sample structure by ownership and sector varies year by year according to the changes recorded in the Top 100 and some biases can appear. In order to decrease the negative influence of these biases, the central tendency indicators (mean, median) and quartiles have been used in comparative analyses.

As the available data are of quantitative nature several statistical methods of data processing have been used. First of all, we computed the evolution of the number of FDI in top 100 largest companies in Romania and the evolution of average turnover between 2003 and 2012. The distribution of companies according to the profit margin has also been obtained. These results provided us the answers to the first two research questions. For the third research question additional quantitative methods have been used, including the Pearson correlation coefficient, Boxplot analysis and the multiple correspondence analysis, also known as the homogeneity analysis (or HOMALS). These analyses had the objective to specifically examine the relative performance of FOS vis-à-vis DCs. We thus render complicated, multivariate data accessible by displaying the main regularities in an easily perceptual map that shows the relationships between categorical variables. The multiple correspondence analysis suits our categorical data as it displays main regularities in pictures such as scatter plots (Michailidis \& De Leeuw, 1998). It provides an easily interpreted perceptual map that jointly shows the relationship between the categorical variables, which is not available through the traditional method of using Chi-Squares 
on a bi-variate level of analysis (Schimmel \& Nicholls, 2005). This method provides a lowdimensional visualisation in which categories and objects are located so each category is the centroid of all objects that score on the category (Van Eck \& Waltman, 2007).

The homogeneity function optimises a weighted least-squares criterion and the optimal graph layout is computed by an alternating least squares algorithm (Michailidis \& De Leeuw, 2005). In essence this analysis for categorical data uses a loss function and algorithm for finding the optimal solution. This technique allows us to scale " $n$ " objects (map them into a low dimensional Euclidean space) in such a way that objects with similar characteristics are close together, while objects with different characteristics are far apart (De Leeuw \& Mair, 2009). The insights from this method are shown through a geometric representation. Thus, the multiple correspondence analysis is often used in economic and social research as it reveals associations between the categories of multiple variables. Nevertheless, taking into consideration the closeness between the categories, we can identify only some associations between the entities that belong to the same group. As the underlying theoretical relationship may not be linear, one cannot infer a cause-effect relationship however and should avoid unwarranted conclusions.

For our data set we used the HOMALS function found in SPSS. Procedurally, the variables are included incrementally in our analyses in order to gradually observe the relationships between difference categories, from a low number of variables to a higher one. Four variables are taken into consideration: turnover, profit margin, economic sector and entry mode. Whenever we apply this method, we use 2012, the last year of data. The decision to use this cross-sectional analysis in relation to 2012 alone is due to the nature of the data, which are mainly categorical data precluding analysis on a longitudinal basis. 


\section{Results and discussion}

\subsection{Entry modes and the characteristics of inward FDI}

Romania went through a protracted economic reform right after the collapse of the Communist regime in 1989: although the process was slow at the beginning, it sped up during mid-2000s when FDI programs were allowed in most sectors, including utilities. Evidence of industrial restructuring as a result of inward FDI was found soon after the EU Accession Agreement was signed in 2003 and large scale privatisation programmes were commenced (Haar, 2010). In fact, the volume of inward FDI to Romania mirrored the privatisation programme. In the 1990s investment took the form of greenfield FDI, while in the next decade acquisitions were favoured. As shown in table 2, by the end of 2012, the total stock of inward FDI to Romania was almost equally divided between these two forms of wholly-owned subsidiaries - greenfield and acquisitions, and constituted the predominant form of FDI during the period under study. In consequence, we focus our analysis on these dominant forms of market entry, acquisitions and greenfield FOS.

[Table 2 here]

The growing relative importance of acquisitions versus greenfield FDI may also be analysed at sector level as acquisitions dominate in manufacturing, mining, utilities and the financial and insurance sectors, while greenfield FDI focused on trade, construction and business services. According to data, the share of foreign affiliates in top 100 companies by turnover almost doubled in the decade, from 38\% in 2003 to 72\% in 2012 (see figure 1). Interpreting the results we can observe that the substitution between FOS and DCs has occurred as a result of either DCs being replaced in the top segment of the market (by revenue) by FOS or being acquired by the latter through privatisation. At company level, greenfield investments were more 
frequent than acquisitions throughout the period, except for 2005 (Finmedia, 2004-2013). Although acquisitions grew at a slower rate (from 16 to 25 companies in 2012) than greenfield (from 22 to 47), together we observe that these accounted for the loss in market position of domestic companies as they declined from $62 \%$ to $28 \%$ in the top largest companies by revenues.

[Figure 1. Share of companies in Top 100 by ownership and entry mode - near here] Source: Authors, Finmedia data

\subsection{Entry modes and corporate performance: average turnover and profit margins}

To compare the relative performance by ownership, we calculated the average turnover for acquisitions, greenfield and domestic companies. Indeed, after 2003, not only did the average turnover of FOS from among top 100 companies in Romania exceed that of DCs, but also acquisitions had an increasingly higher average turnover compared to greenfield FDI (see figure 2). In 2003 the ownership did not seem to matter in terms of average turnover, as all types of companies were largely of equal size, yet, shortly afterwards, the FOS stepped ahead. While the average turnover of FOS increased almost threefold between 2003 and 2012, acquisitions had a higher growth rate in turnover, compared to greenfield FDI. By contrast, DCs grew slowly, especially between 2004 and 2008. This trend can be explained by the start of large scale privatisation deals in 2004. Figure 2 also reveals the impact of the financial crisis on these top companies in Romania as the dip in the turnover across all ownership categories is noticeable between 2008 and 2009. The decline was arrested in the following years and the pre-crisis turnover reached by 2012. Overall, the highest increases in the average turnover were registered in FDI through acquisitions (at 2.96 times the 2003 value), greenfield FDI (at 1.5 times) and DCs 
(at 0.65 times). Thus not only DCs were less numerous in the top echelon, they also grew smaller in relation to their foreign counterparts.

[Figure 2. Average turnover by ownership and entry mode ( $€$ million) - near here] Source: Authors, Finmedia data

Turning to the profit margins earned by FOS, we observe that, by 2012, the majority enjoyed margins of between $1 \%$ and $10 \%$, while almost a third of companies reported losses during the year. To undertake this analysis, we grouped the top 100 companies by turnover into five categories by profit margins, defined as the ratio of gross profit to turnover: loss (negative or zero profit), very low profitability (1-5\%), low profitability (5-10\%), medium profitability (1020\%) and high profitability (over 20\%).

[Figure 3. Profit margin by ownership and entry mode, 2012 (\% of category) - near here] Source: Authors, Finmedia data

In 2012, as seen in figure 3, we note acquisitions had proportionately higher profit margins, while most greenfield FDI earned profit margins of less than 5\%. Nevertheless, the share of greenfield investments reporting losses was lower than the share of acquisitions. In the case of DCs, most of them recorded very low profit margins, but were well represented in the high profit margins categories (sometimes alongside acquisition FOS). This is, however, an important departure from the year before the crisis, e.g. 2006, as seen in figure 4: DCs were struggling financially ( $30 \%$ of them recorded losses, compared to $15 \%$ among FOS, and only a few had profit margins above 20\%). Such performance results may have been the reason why many DCs exited the top 100 list of firms over the last decade. Competition seems to have 
delivered the expected results by creating the conditions for market exit of inefficient incumbents. The remaining DCs were fit enough to withstand competition from foreign rivals. Certainly, one can also take into account a post-crisis effect that favoured DCs based mainly on their national market. These were relatively isolated from the international crisis compared to FOS.

[Figure 4. Profit margin by ownership and entry mode, 2006 (\% of category) - near here] Source: Authors, Finmedia data

Within FOS, prior to the financial crisis, acquisitions performed better than greenfield FOS, partly as a result of acquired DCs with dominant market position as found in oil, energy and automotive. Even if the acquired DC had outdated technology, FOS appear to have benefitted from incumbents' large, established customer base which would take years for greenfield FOS to build. The few DCs with high profit margins were active in strategic sectors such as gas industry and road administration. To rule-out economies of scale as an explanation of why FOS outperformed DC, we calculated the Pearson correlation coefficient to see the extent to which turnover and profit margins are related. We obtained a coefficient value close to zero (0.18) that shows weak correlation between the two variables. The significance level (Sig. 2-tailed) is 0.21 and exceeds the significance level of 0.05 corresponding to a 95\% confidence level. We therefore conclude that profitability does not increase with revenues, i.e. there is no FDI scale effect.

\subsection{Corporate performance: turnover and profit margins at company level}

To avoid the pitfalls of aggregation and obtain further insights into the characteristics of FOS versus DCs, we use the Boxplot analysis which shows the known "5-number summary" 
consisting of the minimum and maximum range values, the upper and lower quartiles, and the median. The median divides the companies in two equal parts, while the Boxplot "whiskers" are extended to the extreme points of the distribution, either the minimum or maximum values in the dataset, calculated by subtracting or adding 1.5 of the inter quartile range. Data exceeding this interval, i.e. outliers, are plotted separately in the chart (Potter et al., 2006). We focused on 2006, 2009, 2012 to compare performance before, during and after the financial crisis. In 2006 we found some asymmetry in the case of acquisitions and greenfield FDI (see figure 5): across all categories by ownership, a high concentration of companies with lower turnover than the median and a higher spread in the upper side of the box can be observed. At $€ 273.3$ million for acquisitions, €335.4 million for greenfield FDI and €317.1 million for DCs, the median turnover recorded by DCs was lower than the median turnover of greenfield FDI but higher than that of acquisitions. The numbers shown in figures 5-7 indicate the rank occupied by companies in Top 100.

[Figure 5. Boxplot analysis for turnover, 2006. Note: Numbers shown in figure indicate the rank occupied by companies in Top 100 - near here] Source: Authors, Finmedia data

By 2009 the same asymmetry can be observed, but the median turnover increased for FOS and decreased for DCs: the median value in 2009 was $€ 332.9$ million for acquisitions, $€ 385.0$ million for greenfield FDI and €265.6 million for DCs (see figure 6). The effect of the financial crisis is observed in the shrinking size of all outliers compared to 2012, although it seems that DCs were affected the most. The year of 2012 brought respite, as seen in figure 7: the median turnover increased to $€ 467.2$ million for acquisitions, $€ 425.2$ million for greenfield FDI and $€ 331.2$ mil for DCs. As before, DCs had still consistently lower turnover compared to FOS. 
This suggests that post-2009 recovery favoured FOS, especially acquisitions, with outliers returning to pre-crisis turnover in excess of €3,000 million.

[Figure 6. Boxplot analysis for turnover, 2009. Note: Numbers shown in figures indicate the rank occupied by companies in Top 100 - near here] Source: Authors, Finmedia data

[Figure 7. Boxplot analysis for turnover, 2012. Note: Numbers shown in figures indicate the rank occupied by companies in Top 100 - near here] Source: Authors, Finmedia data

Summarising, important changes took place over the period, irrespective of the ownership/entry mode category. Despite a consistently high concentration below the median throughout the period, the number of outliers increased suggesting a wider range of companies by turnover within each category, but less so in the case of DCs. The economic recovery post2009 allowed FOS to recapture previous levels of activity, although DCs continued to lag. It seems that DCs had a harder time adjusting to foreign competition and the impact of the financial crisis, hence a slower recovery rate. When we take profit margins into account, acquisition FOS proved the most resilient to the financial crisis. Yet, post 2009, DCs became more profitable in relation to greenfield FOS (figure 8). These DCs are state-owned and enjoy monopoly positions. In aggregate, the median value of profit margins for 2006 was $4.8 \%$ for DCs, 5.2\% for greenfield FDI and 7.6\% for acquisitions: DCs continued to trail behind FOS.

[Figure 8. Boxplot analysis for profit margin, 2006 - near here] Source: Authors, Finmedia data

In 2009 we observe a greater homogeneity in profit margins for acquisitions FOS and a larger spread of values in the upper side of the box (see figure 9). Acquisitions had higher profit margins than both greenfield FDI and DCs. These companies did well despite the financial crisis, 
but with a low profit margin across all sectors. For 2009 the median value of profit margins was of just 2.9\% for DCs, 4.2\% for greenfield FOS and 9.9\% for acquisition FOS. Finally, in 2012, as in figure 10, although acquisitions maintained the lead in terms of profit margins, DCs improved their relative performance versus greenfield FOS. The profit margins of these DC outliers were higher than those of greenfield FOS and, in aggregate, the median value of profit margins reached $4.6 \%$ for DCs, $2.8 \%$ for greenfield and $11.1 \%$ for acquisition FOS.

[Figure 9. Boxplot analysis for profit margin, 2009 - near here]

Source: Authors, Finmedia data

According to our investigations, even though the median turnover of DCs fell behind that of FOS, some DCs have had much higher profit margins compared to FOS counterparts, due to their dominant market positions in certain sectors. Turning to the impact of the sector on the relative performance across ownership categories we see the differences according to company types, as shown in figure 10 below.

[Figure 10. Boxplot analysis for profit margin, 2012 - near here]

Source: Authors, Finmedia data

\subsection{Economic sector and corporate performance}

A snapshot at the distribution of companies by sectors by 2012 shows, as seen in figure 11, that acquisitions favoured industry and services, while greenfield FOS favoured trade and DCs were fairly present in all sectors. This is not surprising considering that the trade sector was built de novo after 1990s.

[Figure 11. Distribution of Top 100 by sector and entry mode, 2012 - near here] 
Source: Authors, Finmedia data

To identify simultaneous relationships between turnover, profit margins, sectors and ownership we used homogeneity analysis as a multivariate statistical method that allowed us to plot 3 categories for turnover, 5 for profit margins, 3 for sectors and 3 for ownership in order to observe a number of clusters explaining the relative performance of DCs versus FOS. The statistical results, as in figure 12, lead to useful observations on the relative performance of companies:

a) DCs are strongly associated with services, medium turnover and high profit margins (10$20 \%)$;

b) Greenfield FOS are closely associated with trade, low profit margins (0-5\%) and low turnover (under €500mil);

c) Acquisitions FOS are mainly associated with the industrial sector and high profit margins (over 20\%); they are closer to small (below €500mil) and large (over €1bn) turnover categories;

d) Companies with the highest turnover (over $€ 1 \mathrm{bn}$ ) are closely associated with loss and industry.

[Figure 12. Homogeneity analysis between entry mode, turnover, profit margin and sector - near here] Source: Authors

\section{Conclusions}

The aim of this research has been to compare the performance over a decade of the largest 100 companies (by turnover) in Romania and, thereby, extend and apply the existing literature to an interesting period in which economic reform and liberalisation allowed foreign owned firms to 
enter previously closed markets and compete with domestic entities which had long been shielded from competition. Through comparing the performance of domestic companies (DCs) and foreign-owned subsidiaries (FOS) during a key period in economic history, the analysis allowed a comparative analysis using financial indicators and modes of entry according to sector. Applying multi-variate statistical methods to the categorical data we have found strong associations between the categorical variables for turn-over, profit margins, and sectors. The visualisation of the multiple correspondence statistical analysis in the graphs above shows the associations as clusters, the identification of which allowed us to draw inferences on the relative performance between DCs and FOS.

Importantly, these 'clusters' also reflect relationships between ownership, entry modes and sectors. This has important normative implications as policymakers try to maximise the benefits to DCs from inward FDI. Although it is generally acknowledged in the literature that FDI has made an important contribution to the economic development in CEE transition countries, Romania included, either through greenfield FDI or through acquired domestic firms (see Meyer, 2001), how our DCs have fared in comparison to FOS since this process began has not been researched

Addressing our first research question, we found evidence supporting the proposition that the structure of industry changed. Post entry, measured by size and turn-over, FOS became the largest firms in the country while DC were relegated a lower status. We found that competition from FOS, with superior firm-specific advantages, led over time to differences in turn-over and profit margins that removed half of DCs from of the top 100 largest firms in Romania by 2012. For example, in terms of number of companies, DCs dominated the top 100 list until 2009. Afterwards, they were taken over by greenfield FOS. We observed that the scope for undertaking 
FDI through acquisitions was limited by the gradual opening of the domestic market to foreign competition through privatisation and liberalisation reforms. However, in terms of inward FDI stock to Romania, by 2012 acquisitions and greenfield FOS were equally important. By median turn-over, companies acquired by FOS consistently outperformed both greenfield FOS and DCs in 2012 in comparison with a decade earlier. Thus policy makers should have no illusions with regard to how opening an economy may change the economic landscape. FOS answering to the concerns of global shareholders may have very different priorities to DC with local ownership and domestic stake-holders.

On our second research question with regard to differences in profitability between DCs and FOS, we found that during the period under study, median performance increased. Between 2003 and 2008 FDI was associated with improved profit margins for FOS, superior to those enjoyed by DCs. Nevertheless, average profit margins declined after 2009, with the exception of DCs among whom some performed better than FOS, especially of greenfield type, although some of this effect may be attributable to the global financial crisis. Interestingly, the better performance of DCs was limited to those sectors where state ownership was prevalent. The superior performance may be the result of a privileged market positions, if not de-facto monopoly power. Critically, we found that, at company level, profitabilty was not associated with greater turn-over. Economies of scale or other benefits from size were not the source of greater return on equity. Profitability was invariant to size. Rather, higher profits were associated with specific market structure as enjoyed by companies operating mainly in telecommunications, gas and oil industries (the case of DCs and acquisition FDI). It may be the case that, during the periods of deregulation and market opening, latent advantages to such sectors as may arise from vertical integration and network ownership, were now available for exploitation, 
whereas previously through state ownership, they had been under control. To the extent that greater profitability resulted in economic rents, extracting consumer surplus from consumers in formal terms, there may be role for regulators to consider regulation if greater levels of competition through foreign entry cannot be achieved. Therefore, while the majority of the largest companies in Romania profit margins were restrained by competition, infrastructurebased industries, with latent natural monopoly advantages, enjoyed superior returns. In the electricity and telecommunications sectors where DC had ownership positions in both networks as well as in supply and distribution, it appears that distinct advantages were exploited compared to FOS which lacked the benefits of vertical integration or a captive base of retail customers.

Turning to our third research question we found large differences in various corporate finance metrics between sectors. The results are consistent with our observations for the second research question, comparing network and natural monopoly industries with, say, manufacturing sectors. Our statistical analysis revealed important associations among variables that explain some differences in relative performance. For example, DCs were strongly associated with the service sector, high profit margins and medium turnover. Acquisitions FOS were strongly associated with primary industries. Evidently, FOS perceived such upstream primary industries as having the greatest scope for economic rents and facing the least level of competition. Romania ranks tenth in the world in diversity of its mineral deposits making acquisitions in this sector quite interesting and arguably more attractive than acquiring a manufacturing firm, for example, in precision instruments. Unlike DCs involved in services, the profitability of FOS involved in industry varied, having a symmetric distribution of returns. Meanwhile, greenfield FOS were strongly associated with trade, small turnover and low profit margins. Although one must be careful in comparing the performance of sectors according to profitability ignoring their 
inherent risk, we see firms with similar risk levels and varying levels of profitability. From our results, based upon the factors analysed, corporate performance depends largely on the sector in which companies operate as opposed to size, ownership or mode of entry.

There are limitations to this research, mostly related to the data available. Other economic indicators such as employment, exports and linkages generated by FOS would have supplemented this study and made it possible to apply regression analysis to determine closer links between our variables, as opposed to strong cluster-based associations. In addition, by focusing on the largest companies in Romania, this study does not take into account the performance of the emerging domestic private companies. Nevertheless, this analysis contributes to understanding the state-of-play of corporate performance in Romania as we have highlighted positive associations between key metrics supporting the proposition that competition is working. This holds important lessons for policymakers in Romania and for those in CEE in general. Firstly, they should continue to encourage inward FDI while pursuing privatisation reforms in infrastructure-related industries where state-owned incumbents remain unchallenged. However, as the results show, natural monopolies generally enjoy high profits, irrespective of the origin of ownership. The partial opening of such sectors appears to have allowed domestic incumbents to exploit latent advantages, such as vertical integration and networks, while backfooting FOS. Where vertical integration may confer network advantages, such as in energy transmission and distribution, unbundling of assets, as has been used in other countries should be considered. Unless the true agenda is merely to promote FDI to re-build tired infrastructure while leaving the rewards for domestic incumbents, a more level playing field should be considered.

Therefore, privatization of the remaining state companies, such as energy utilities, should be approached with care by Romanian authorities to ensure that inherent advantages are simply 
not transferred to FOS but rather that market re-design is considered. Thus, encouragement of foreign ownership should involve a clear investment and growth plan rather short-term fiscal considerations. The case for selling an asset conferring economic rents should be examined from the standpoint of long-term economic efficiency. Promoting economic allocative efficiency should be paramount. Thirdly, in conformity with EU regulations, non-economic factors such as the protection of local cultures or communities should be included in plans for privatization in such sectors as manufacturing. Economic development should involve transforming tired domestic companies into world-class entities, not eliminating productive assets and transmogrifying the country into a nation of consumers, purchasing goods and services produced abroad. Finally, policymakers may wish to look beyond accounting metrics and think strategically about industries and sectors to choose companies with scope for modernisation and growth, rather than mere short-term profitability, for example. We believe the research provides lessons for other countries seeking to open their economies to foreign ownership and competition both with regard to what sectors should be selected and what metrics used to measure success.

\section{References}

Aitken, B.J., \& Harrison, A.E. (1999). Do domestic firms benefit from direct foreign investment? Evidence from Venezuela. American Economic Review, 89, 605-618. doi: 10.1257

Ashraf, A., \& Herzer, D. (2014). The effects of greenfield investment and M\&As on domestic investment in developing countries. Applied Economics Letters, 21, 997-1000. doi: 10.1080 Bandelj, N. (2010). How EU Integration and Legacies Mattered for Foreign Direct Investment into Central and Eastern Europe. Europe-Asia Studies, 62, 481-501. doi: 10.1080 
Barbosa, N., \& Louri, H. (2005). Corporate performance: does ownership matter? A comparison of foreign and domestic-owned firms in Greece and Portugal. Review of Industrial Organization, 27, 73-102. doi: 10.1007

Bellak, C. (2004). How domestic and foreign firms differ and why does it matter? Journal of economic surveys, 18, 483-514. doi: 10.1111

Buckley, P., \& Casson, M. (1976). The Future of the Multinational Enterprise. Basingstoke: Macmillan.

Caves, R. (1996). Multinational Enterprise and Economic Analysis. Cambridge: Cambridge University Press.

Damijan, J.P. et al. (2013). Impact of firm heterogeneity on direct and spillover effects of FDI: micro-evidence from ten transition countries. Journal of Comparative Economics, 41, 895-922. https://lirias.kuleuven.be/handle/123456789/557351

De Leeuw, J., \& Mair, P. (2009). Gifi Methods for Optimal Scaling in R: The Package homals. Journal of Statistical Software, 31, 1-21. doi: 10.18637

Dunning, J.H. (1973). The determinants of international production. Oxford Economic Papers, 25, 289-336. doi: 10.1093

Findlay, R. (1978). Relative backwardness, direct foreign investment and the transfer of technology: a simple dynamic model. Quarterly Journal of Economics, 92, 1-16. doi: 10.2307 Finmedia. (2004-2013). Romania Top 100 Companii. Bucharest: CERME.

Ghauri, P.N., \& Yamin, M. (2009). Revisiting the impact of multinational enterprises on economic development. Journal of World Business, 44, 105-107. doi: 10.1016

Haar, L. (2010). Industrial Restructuring in Romania from a Bilateral Trade Perspective: Manufacturing Exports to the EU from 1995 to 2006. Europe-Asia Studies, 62, 779-805. 
https://www.research.manchester.ac.uk/portal/en/facultiesandschools/alliance-manchesterbusiness-school(b7ec585d-9a22-4d60-b65c-1280711bd728)/publications.html?page=461

Haar, L., \& Marinescu, N. (2014). Entry Modes and Firm Performance in a Transition Economy: Evidence from Inward FDI to Romania. Journal of East-West Business, 20, 44-67. doi: 10.1080 Hamida, L.B. (2013). Are there regional spillovers from FDI in the Swiss manufacturing industry? International Business Review, 22, 754-769. http://isiarticles.com/bundles/Article/pre/pdf/41393.pdf

Hardy, J. et al. (2011). Upgrading Local Economies in Central and Eastern Europe? The Role of Business Service Foreign Direct Investment in the Knowledge Economy. European Planning Studies, 19, 1581-1591, doi: 10.1080

Hunya, G. (2001). Uneven competitiveness of industries in the wake of foreign penetration in advanced transition economies. Transnational Corporations, 10, 35-66.

https://www.econbiz.de/Record/uneven-competitiveness-of-industries-in-the-wake-of-foreignpenetration-of-advanced-economies-in-transition-hunya-g\%C3\%A1bor/10001655025

Hymer, S.H. (1976). The international operations of national firms: a study of direct foreign investment. Cambridge, MA: MIT Press.

Javorcik, B. (2004). Does Foreign Direct Investment Increase the Productivity of Domestic Firms? In Search of Spillovers through Backward Linkages. American Economic Review, 94, 605-627. doi: 10.1257

Javorcik, B.S., \& Spatareanu, M. (2011). Does it matter where you come from? Vertical spillovers from foreign direct investment and the origin of investors. Journal of Development Economics, 96, 126-138. http://isiarticles.com/bundles/Article/pre/pdf/9606.pdf 
Jensen, C. (2006). Foreign Direct Investment and economic transition: Panacea or pain killer? Europe-Asia Studies, 58, 881-902. doi: 10.1080

Jenkins, R. (1990). Comparing foreign subsidiaries and local firms in LDCs: theoretical issues and empirical evidence. The Journal of Development Studies, 26, 205-228. doi: 10.1080

Majumdar, S.K. (1997). The impact of size and age on firm-level performance: some evidence from Indian industry. Review of Industrial Organization, 12, 231-241. doi: 10.1023

Marinescu, N., \& Constantin, C. (2010). The Link between Exports and Foreign Direct Investment: The Case of Romania. Studia Universitatis Babes-Bolyai, Negotia, LV, 71-84. http://studia.ubbcluj.ro/download/pdf/982.pdf

Markusen, J.R. (1995). The boundaries of multinational enterprises and the theory of international trade. Journal of Economic Perspectives, 9, 169-189. doi: 10.1257

Mata, J., \& Portugal, P. (2004). Patterns of entry, post-entry growth and survival: a comparison between domestic and foreign owned firms. Small Business Economics, 22, 283-298. doi: 10.1023

Mehic, E. et al. (2013). The impact of FDI on economic growth: some evidence from Southeast Europe. Emerging Markets Finance and Trade, 49, 5-20. doi: 10.2753

Meyer, K. (2001). Institutions, Transaction Costs and Entry Modes Choice in Eastern Europe. Journal of International Business Studies, 31, 357-367. doi: 10.1.1.333.5320

Michailidis, G., \& De Leeuw, J. (1998). The Gifi System of Descriptive Multivariate Analysis. Statistical Science, 13, 307-336. https://projecteuclid.org/euclid.ss/1028905828

Michailidis, G., \& De Leeuw, J. (2005). Homogeneity analysis using absolute deviations. Computational Statistics \& Data Analysis, 48, 587-603. doi: 10.1016 
Narula, R., \& Driffield, N. (2011). Does FDI cause development? The ambiguity of the evidence and why it matters. European Journal of Development Research, 24, 1-7. doi: 10.1.1.427.584

Narula, R., \& Dunning, J.H. (2010). Multinational Enterprises, Development and Globalisation: some clarifications and a research agenda. Oxford Development Studies, 38, 263-287. doi: 10.1080

Navaretti, G.B., \& Venables, A.J. (2013). Multinationals and industrial policy. Oxford Review of Economic Policy, 29, 361-382. doi: 10.1093

Nguyen, Q.T.K. (2011). The empirical literature on multinational enterprises, subsidiaries and performance. Multinational Business Review, 19, 47-64. doi: 10.1108

Nguyen, Q.T.K. (2013). Can British multinational enterprises finance economic development in South East Asia? Multinational Business Review, 21, 122-147. doi: 10.1108

Nguyen, Q.T.K., \& Rugman, A.M. (2015). Multinational subsidiary sales and performance in South East Asia. International Business Review, 24, 115-123. doi: 10.1016

Nitsch, D. et al. (1996). Entry Mode and Performance of Japanese FDI in Western Europe. Management International Review, 36, 27-43. doi: 10.5923

Potter, K. et al. (2006). Methods for Presenting Statistical Information: The Box Plot. Visualization of Large and Unstructured Data Sets, 4, 97-106. https://www.cs.vt.edu/node/1787 Romanian National Bank. (2013). Investitiile straine directe in Romania. Bucharest: BNR.

Rugman, A., \& Verbeke, A. (2001). Subsidiary-specific advantages in multinational enterprises. Strategic Management Journal, 22, 237-250. doi: 10.1002

Sanchez-Sellero, P. et al. (2014). Spillovers from foreign direct investment in Spanish manufacturing firms. Review of International Economics, 22, 342-351. doi: 10.1111 
Schimmel, K., \& Nicholls, J. (2005). Media mix elements that motivate online shopping. Journal of Website Promotion, 1, 53-63. doi: 10.1300

Szentpeteri, A., \& Telegdy, A. (2012). Political objectives and privatization decisions. Economics of Transition, 20, 299-313. doi: 10.1111

UNCTAD. (2000). World Investment Report 2000: Cross-Border Mergers and Acquisitions and Development. New York and Geneva: United Nations.

UNCTAD. (2004). World Investment Report 2004: The Shift Towards Services. New York and Geneva: United Nations.

Van Eck, N.J., \& Waltman, L. (2007). Applying Ideas from Homogeneity Analysis to Visualize Similarity Data. Working paper. Rotterdam: CARME.

Wang, J., \& Wang, X. (2015). Benefits of Foreign Ownership: Evidence from Foreign Direct Investment in China. Journal of International Economics, 97, 325-338.

http://www.cf40.org.cn/uploads/PDF/xx2.pdf 